\title{
CRT 後の喉頭摘出術の合併症一予防と対策
}

\author{
菅澤正
}

要旨：CRT は進行喉頭癌に対する機能温存治療として, 大きな役割を担っているが, 一定の割合で再発を生 じる。その救済手術は，頭頸部外科医の大きな課題で有り，喉頭癌においては咽頭皮膚瘦の予防が，ポイント となる。救済手術時の，瘦孔予防策について 41 施設より聞き取り調查を行った。約半数の施設では，特別な 対策を講じていなかった。6 施設では，遊離空腸移植や，大胸筋弁による粘膜縫合部の裏打ち，DP 皮弁によ る頸部皮膚張り替えなどの積極的予防策を講じていた。残りの施設はハイリスク症例に対して, 様々な対策が 講じられている。前向き試験の無い現在, 今後は多施設のデー夕を集積解析し, 予防処置の適応と術式の標準 化が望まれる。

キーワード：喉頭全摘，咽頭皮膚瘻，大胸筋弁，DP 皮弁，死腔

\section{はじめに}

Pignonのメタアナライシスにより, 頸部扁平上 皮癌に対する化学放射線療法 (Chemoradiotherapy：CRT）は，放射線単独治療に比べて高い奏効 率が得られることが示され ${ }^{1)}$, 現在, 咽頭喉頭進行 癌に対する機能温存治療として，大きな役割を担っ ており，その割合も増加の一途をたどっている。し かしながら，一定の割合で残存，再発を生じ，その 制御は頭頸部外科医の大きな課題となっている。喉 頭癌においては, 救済手術の際の咽頭皮膚瘦の予防 がポイントとなる。本稿では咽頭皮膚瘦発生の実態 とその対策について自施設の成績を報告すると共 に, 全国がんセンター, 大学附属病院 41 施設から, 合併症予防策について，聞き取り調查を行ったので 報告する。

\section{咽頭皮膚瘻の実態}

最初に当科の現状を示す。対象は 2007 年 4 月よ り 2014 年 12 月まで, 一次治療を行った, 喉頭扁平 上皮癌 183 例中, 声門下がん 5 例を除く 178 例であ る。男性 172 例, 女性 11 例, 年齢は $35 \sim 97$ 歳, 平均 69 歳であった。ステージ I, II, III, IV はそ れぞれ，74，34，27，43 例であった。図 1 に喉頭 進行がんの治療アルゴリズムを示す。CRT は標準 的治療選択肢の一部として, 治療体系に組み込まれ ている。当科の喉頭進行がんに対する治療方針は喉 頭全摘であるが, 発声機能温存希望者に対しては, リスクを説明した上で, 化学放射線療法を施行して

埼玉医科大学国際医療センター頭頝部腫瘍科・耳鼻咽喉科 [平成 28 年 8 月 29 日受付, 平成 28 年 11 月 29 日受理]
いる。80 歳以上の高齢者, 糖尿病, 腎機能低下な ど併存症の重篤な症例は，喉頭全摘術を選択した。 70 例に放射線治療， 36 例に CRT が施行された ${ }^{2)}$ 。 喉頭全摘術施行例は 64 例であった。その内訳は 初回手術例 51 例, 照射後再発例 14 例であった。 CRT 後は組織の線維化, 血流障害, 化学療法によ る全身状態の悪化により治療後早期から合併症のリ スクは高く, 肉芽増生不良のため, 一旦生じた感染 は重篤になりがちで, 頸動脈破裂など致命的な障害 を引き起こしかねない。当科の非照射例, 照射例の 咽頭皮膚瘦孔形成はそれぞれ 7 例, 3 例で発生率は, $13.7 \%, 21.4 \%$ であり有意差（p=0.44）は認めず, 諸家の報告に比べて, 照射例で若干少なめであっ た。初回手術例の喉頭全摘では当科の結果と同様, 癭孔形成率は $10 \%$ 程度であるとの報告が多いが, 根治照射後は $30 ＼mathrm{~ 60 \% に 達 す る と さ れ て い る ~}{ }^{3-5)}$ 。 必ずしも化学療法の併用で発生率が上昇する訳では ないが，一度，合併症を起こすと重篤化し，治療に 難渋したとの報告は多い。CRT 後の症例では図 $2 \mathrm{a}$ に示されるように, 唾液の流出で感染を起こし壊死 組織が限局せず拡大してゆくことが多く, 肉芽瘦で の閉鎖は期待できない。図 2 に示す, 様々な療法が 行われているが保存的治療では閉鎖困難で外瘦を形 成し，有茎皮弁で閉鎖を行う例が多いが，時に数回 の手術が必要となり, 経口摂取まで, 数か月を要 し，患者の負担も大きい。

当科の経験でも照射後㾇孔症例の 3 例はいずれも CRT後で手術から閉鎖までの期間はそれぞれ53日， 200 日，133 日と長期を要した（平均 128.6 日）。初 回手術群では平均 48.8 日で（ $\mathrm{p}=0.0667 ）$ 有意差は ないが， CRT 群が著明に長引く傾向であった。 


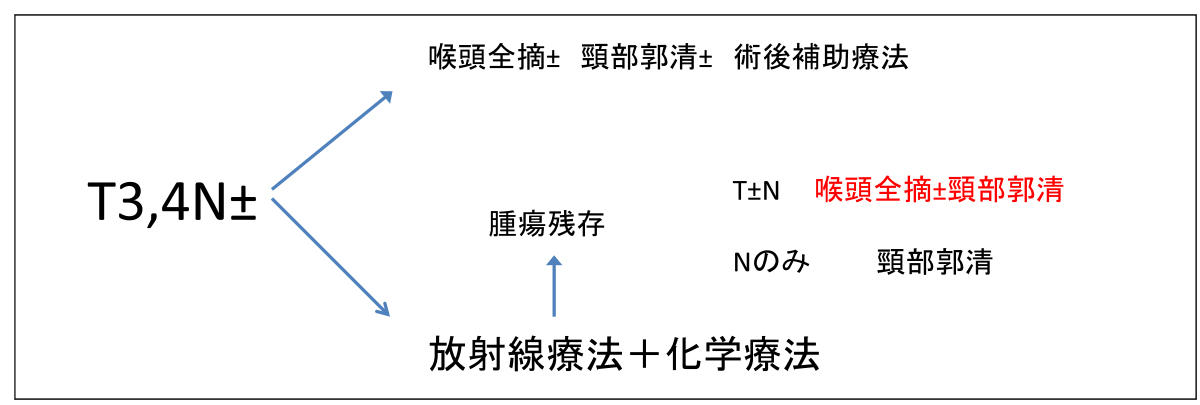

図 1 喉頭局所進行癌の治療アルゴリズム（2013 年度版頭頸部癌診療ガイドラ インより）

T3 で 70 〜 80\%，T4 で 20〜 50\%程度の喉頭機能温存が期待できる。

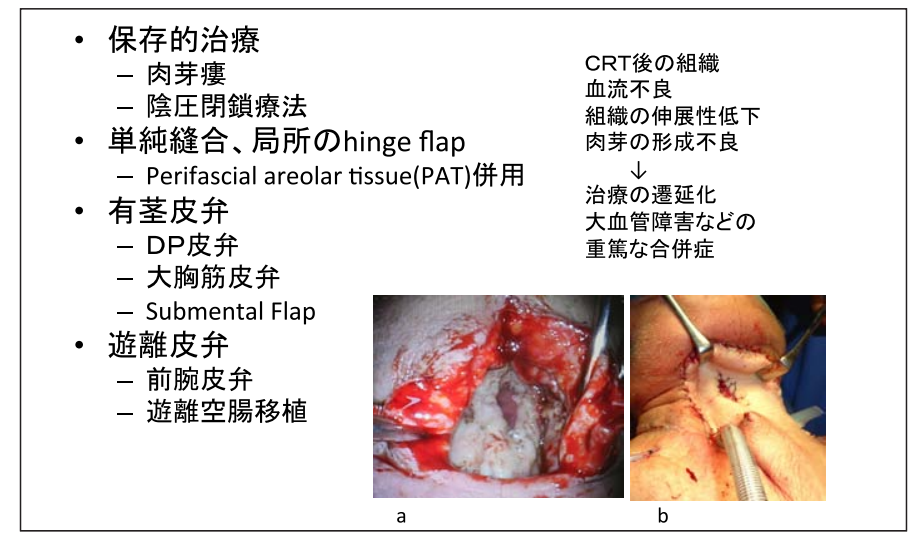

図 2 咽頭皮膚瘦の治療法

a. CRT 後の咽頭皮膚瘦所見。感染により, 瘻孔周囲組織 の変性は高度である。

b. DP 皮弁による, 外瘻形成術後後

さて，当科では $\mathrm{CRT}$ 後の喉頭全摘においても, 特別の合併症予防策は取っていない。外科手術の原 則である愛護的な操作に留意し残存粘膜の緊張, 血 流に注意し, 可能な限り 3 点縫合を作らず縫合して いる。咽喉頭摘出例と異なり, 今回検討した喉頭全 摘出術症例では皮下の死腔予防のため, DP 皮弁等 で皮膚を張り替えた症例は無かった。

\section{予防手技}

大胸筋弁による咽頭縫合部の裏打ち, DP 皮弁に よる皮虐張り替えなど, 様々な予防策が報告されて いるが，標準化された手技は無く，施設間格差も大 きいと思われるので, 大学病院, がんセンター総計 41 施設より聞き取り調查を行った。その聞き取り 内容は。具体的咽頭皮膚瘦予防策と, どのような症 例に施行するのか，そして，周術期の工夫である。 その結果を表 1 に示す。

約半数の施設 (20) では, 術式の変更を行ってい なかった。16施設では, 全身, 局所の状態によっ ては，何らかの予防措置を執っていた。5 施設では 積極的にDP 皮弁による頸部皮虞の張り替え, 大胸
筋皮弁（PMMC） あるいは遊離空腸移植あるいは 外瘦形成など予防策を講じていた。項目毎に詳細に 述べる。

1. 術式の変更 (表 2)

CRT 後の症例に対し, 通常の喉頭全摘では無く, 手術プランそのものを変更するものである。死腔の 形成を予防するための方法として, 小リンパ節転移 はCRTにより制御されると見なし，通常併施する 頸部郭清術の省略, あるいは郭清範囲を縮小させ る。CRT 後の皮弁は一般に浮腫状で伸展性に欠け, 肉芽の上がりも不良であり, 皮弁下に死腔を生じ易 いので, 頸部皮膚の DP 皮弁のよる置き変えなどで ある。縫合不全を予防する目的で, 血流の悪い粘膜 を大きく切除し, 咽喉頭摘出として血流の良い遊離 空腸移植に変更も考慮されている。全身状態の悪い 患者では, 咽頭皮膚瘦を回避するため, 一期的に咽 頭再建を行わず外瘦を形成し，二期的に閉鎖すると の施設もあった。欧米では, 血流の豊富な大胸筋弁 で咽頭縫合部を裏打ちし, 創傷治癒促進をはかる試 みが積極的に行われており，瘦孔形成が $36 〜 45 \%$ 
表 1 咽頭皮膚瘻予防に対する各施設の対応 約半数の施設で，何らかの予防策が講じられていた。

- 通常の喉頭全摘 20施設

- 一部の症例で予防措置 16 施設

- DP, PMM, 遊離空腸、外瘻
表 2 咽頭皮膚瘻予防策: 術式の変更

\section{- 死腔形成予防}

-DP皮弁による頸部皮膚張り替え

一頸部郭清省略、範囲縮小

- 創傷治癒促進 一大胸筋(皮) 弁(PMMC)による咽頭縫合部の裏打 ち

- 合併症予防

一外瘻形成

- 遊離空腸移植
表 3 喉頭全摘手技の工夫

- 皮切

- T字切開

- 横切開で気管孔との連続避ける

- 皮弁

一筋膜など付け厚めに挙上し、愛護的に

- 粘膜縫合

- 三点縫合避ける

ー バイトを厚めにして縫合間隔 $(4 \sim 7 \mathrm{~mm})$ を空ける

一咽頭収縮筋でカバー

一絹糸を使用
表 4 周術期の工夫

・プロスタグランディン製剤投与

・ドレーンを多めに、長期留置

- 創部圧迫

・術後5病日に小切開加え、貯留液の確認

- 機能栄養食品による栄養状態改善
・咽頭瘻のリスクファクター
- CRT後
- T進行例
- 両側頸部郭清例
- Surgical margin陽性
- PS不良例
- DM
- 貧血
- 輸血症例
- 低アルブミン

・ 微熱の持続

・皮膚の発赤

- 皮弁の浮腫

- CRP高値の遷延

- 瘻孔発現時期の遅れ - 術後2W以降にも

疑わしいときは CT、内視鏡で観察を

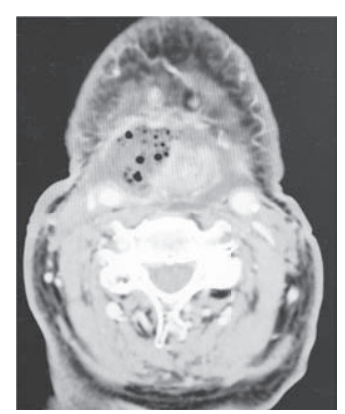

図 3 早期発見
から 10 ～14\%に減少したと報告されており，本邦 でも数施設で症例を選択して行われている6,7)。

2. 喉頭全摘手技の工夫（表 3）

喉頭全摘出術そのものの工夫もいくつか報告され たので列挙する。皮膚切開の工夫として，通常の逆 $\mathrm{U}$ 字では無く, T 字あるいは一本腺として, 瘻孔を 早期発見し易くすると共に，瘦孔形成時の処置も容 易とするあるいは，上方の横切開で喉頭摘出を行 い, 気管孔部は別に切開を置き, 上方の皮切と連続 させないなどである。

皮弁を作成する際も，下層の舌骨下筋群筋膜まで 含めて, 厚めに挙上し血流を確保し, 術中も湿潤 ガーゼで保護し乾燥に注意する事も重要である。
粘膜縫合に関しては横 1 線あるいは縦 1 線で行 い, 3 点縫合を作らない様にして, 更に咽頭収縮筋 で粘膜縫合部をカバーする。縫合時も, バイトを厚 めに取り，あまり細かく縫わず，4 から $7 \mathrm{~mm}$ の間 隔で, 絞めすぎない事も重要である。粘膜縫合は吸 収糸で行う施設が大半であるが，絹糸を好んで用い る施設もあった。創部感染により, 吸収糸の吸収は 早まることから, 感染のリスクの高い部位の抗張力 性の維持が目的であろうか。

3. 周術期の管理 (表 4)

局所の血流改善を目的にプロスタグランディン製 剤を投与している施設もある。一般にドレーンを多 め，長期に留置することが推奨されている。 
死腔形成, 瘦孔形成の確認のため, 術後 5 日目 に, 皮膚縫合部を 1,2 針抜糸し, 直接貯留液が有 るか確認を行うとの施設もあった。当科では陰圧ド レーンの普及後, 創部の圧迫は行っていないが, あ らためて圧迫の重要性を強調する施設もあった。

以上のように施設により様々な工夫がなされている。 咽頭皮膚瘻のリスクファクターとして, 貧血, 低 アルブミン, T 進行例, 両側頸部郭清例, 全身状態 不良例などが挙げられているが（表 5)，どのよう な症例に積極的に予防策を行うべきか未だ確立して おらず，各施設の経験から様々な処置がとられてい るのが現状である。今回の調査では, 何らかの予防 策を取っている施設は三分の一程度で, 多くの施設 は丁寧で愛護的基本的手術操作で対応可能であると の回答であった。頸動脈破裂などの重篤な合併症を 経験した施設で何らかの積極的予防措置を施行する ことが多かった。

CRT 後の術後管理の要点は, 合併症を最小限に 食い止めるために, 異常所見を早期に発見する事で ある（図 3 )。術後 7,8 病日で出現する弛張熱の出 現，一端下がった CRP 值の上昇などを観た場合， 内視鏡, エコー, 場合によっては CT 撮影などで死 腔, 膿瘍の形成を早期に確認する。先行する発熱に 引き続いて, 皮膚の浮腫, 疼痛或いは圧痛, 発赤が 出現すれば，かなり疑わしく，エコー等でも膿瘍形 成がはっきりしない場合でも，試験的に創部の一部 開放を躊躇してはならない。

\section{まとめ}

各施設, それぞれの CRT 後の咽頭皮膚瘻予防手
技について解説した。前向き試験の無い現在, 多施 設のデー夕を集積解析し, 予防処置の適応と術式の 標準化が望まれる。

\section{著者は申告すべき利益相反を有しない。}

\section{文献}

1) Pignon JP, Bourhis J, Domenge C, et al: Chemotherapy added to locoregional treatment for head and neck squamous-cell carcinoma: three meta-analyses of updated individual data. Lancet $355: 949-958$, 2000.

2）久場潔実, 小柏靖直, 中平 光彦, 他: 当科に扔ける 喉頭癌の臨床的検討. 喉頭, $28: 10-15,2016$.

3）篠崎 剛, 西野 宏, 金沢英哲, 他: 喉頭全摘出後 咽頭皮膚瘦についての検討. 頭頸部外, $17: 249-$ 254, 2007.

4）中西庸介, 脇坂尚宏, 室野重之, 他: 喉頭全摘後の 咽頭皮膚瘦の発生. 頭頸部癌, $26: 48-52,2010$.

5）古田康, 本間明宏, 折館伸彦, 他：喉頭がんに対 する化学放射線療法後 salvage 手術に関する検討. 頭頸部癌, $33: 356-360,2007$.

6) Gilvert MR, Sturm JJ, Gooding WE, et al: Pectoralis major myofascial onlay and myocutaneous flaps and pharyngocutaneous fistula in salvage laryngectomy. laryngoscope $124: 2680-2686,2014$.

7) Gendreau-Lefevre AK, Audet N, Maltais S, et al: Prophylactic pectoralis major muscle flap in prevention of pharyngocutaneous fistula in total laryngectomy after radiotherapy. Head and Neck 37 : 1233-1238, 2015. 